\title{
Identification and characterisation of a novel adhesin Ifp in Yersinia pseudotuberculosis
}

\author{
Philippa CR Strong ${ }^{1}$, Stewart J Hinchliffe ${ }^{1}$, Hannah Patrick², Steve Atkinson², Olivia L Champion ${ }^{3}$ and \\ Brendan W Wren ${ }^{1 *}$
}

\begin{abstract}
Background: In order to identify new virulence determinants in Y. pseudotuberculosis a comparison between its genome and that of Yersinia pestis was undertaken. This reveals dozens of pseudogenes in Y. pestis, which are still putatively functional in Y. pseudotuberculosis and may be important in the enteric lifestyle. One such gene, YPTB1572 in the Y. pseudotuberculosis IP32953 genome sequence, encodes a protein with similarity to invasin, a classic adhesion/invasion protein, and to intimin, the attaching and effacing protein from enteropathogenic (EPEC) and enterohaemorraghic (EHEC) Escherichia coli.

Results: We termed YPTB1572 Ifp (Intimin family protein) and show that it is able to bind directly to human HEp-2 epithelial cells. Cysteine and tryptophan residues in the C-terminal region of intimin that are essential for function in EPEC and EHEC are conserved in Ifp. Protein binding occurred at distinct foci on the HEp-2 cell surface and can be disrupted by mutation of a single cysteine residue at the C-terminus of the protein. Temporal expression analysis using lux reporter constructs revealed that ifp is expressed at late log phase at $37^{\circ} \mathrm{C}$ in contrast to invasin, suggesting that Ifp is a late stage adhesin. An ifp defined mutant showed a reduction in adhesion to HEp-2 cells and was attenuated in the Galleria mellonella infection model.
\end{abstract}

Conclusion: A new Y. pseudotuberculosis adhesin has been identified and characterised. This Ifp is a new member in the family of invasin/intimin outer membrane adhesins.

\section{Background}

Within the genus Yersinia there are three human-pathogenic species; Y. pestis, the causative agent of plague, and two enteric pathogens, Y. pseudotuberculosis and $Y$. enterocolitica. Despite the differences in disease, $Y$. pestis and $Y$. pseudotuberculosis are very closely related at the genetic level. $Y$. pestis is believed to have evolved from $Y$. pseudotuberculosis between 1,500-20,000 years ago [1]. Thus, in a remarkably short length of evolutionary time, $Y$. pestis has evolved from an enteropathogen, to a blood-borne pathogen with an insect vector [2]. Genome sequencing of several $Y$. pseudotuberculosis and $Y$. pestis strains, revealed that $Y$. pestis has accumulated a large number of pseudogenes since its divergence. By the "use it or lose it" paradigm, this is suggestive of the

\footnotetext{
* Correspondence: brendan.wren@lshtm.ac.uk

${ }^{1}$ Pathogen Molecular Biology Unit, Department of Infectious and Tropical Diseases, London School of Hygiene and Tropical Medicine, London, WC1E 7HT, UK

Full list of author information is available at the end of the article
}

decay of those genes that are no longer required for function as $Y$. pestis adapts to a new lifestyle [3,4]. Gene disruption may also result in pathoadaptive mutation, whereby loss of gene function results in an increase in virulence [5]. This has been demonstrated in several pathogenic bacteria including Shigella spp. and Escherichia coli [6,7]. Pathoadaptive mutations have previously been identified in $Y$. pestis, with the negative regulators of biofilm formation, $r c s A$ and $n g h A$, being disrupted, resulting in the ability of $Y$. pestis to form biofilms within the flea vector $[8,9]$.

Pseudogenes in $Y$. pestis that are known to be essential for the enteric lifestyle of $Y$. pseudotuberculosis, include the adhesins YadA and invasin $[3,10,11]$. Invasin was one of the first bacterial virulence factors identified, when it was observed that the inv gene alone was sufficient to convert benign non-invasive laboratory $E$. coli strains, to being capable of invading tissue culture cells [12]. Invasin is a $103 \mathrm{kDa}$ protein that is capable of binding to $\beta 1$ integrins on the host cells, promoting internalisation of
C Biomed Central

(c) 2011 Strong et al; licensee BioMed Central Ltd. This is an Open Access article distributed under the terms of the Creative Commons Attribution License (http://creativecommons.org/licenses/by/2.0), which permits unrestricted use, distribution, and reproduction in any medium, provided the original work is properly cited. 
the bacterium [13]. During early infection, invasin specifically binds $\beta 1$ integrins on the apical surface of $M$ cells, which facilitates efficient translocation to the underlying Peyer's patches [14]. The invasin protein is composed of a short N-terminal transmembrane domain, four structural bacterial immunoglobulin domains (bIg domains) and a C-type lectin-like domain [15]. The last bIg domain and the C-type lectin-like domain comprise the functional $\beta 1$ integrin binding region $[15,16]$.

In the same family of bacterial adhesion proteins as invasin, is intimin, an important adhesin expressed by enteropathogenic (EPEC) and enterohaemorrhagic (EHEC) E. coli on the LEE pathogenicity island [17]. Intimin is a $94 \mathrm{kDa}$ outer membrane protein that is also found in Citrobacter freundii and Hafnia alvei $[17,18]$. The functional binding domain of intimin is located in the 280 amino acid C-terminal region, and consists of two bIg domains and a C-type lectin-like domain, which are structurally similar to invasin $[15,18,19]$. When EPEC and EHEC colonise the small intestine mucosa, a characteristic attaching and effacing lesion is formed. First there is localised destruction (effacement) of the microvilli, which leads to intimate attachment of the bacterium to the host cell [20]. EPEC and EHEC encode a specific intimin receptor, translocated intimin receptor (Tir). This receptor is translocated directly into the host cells via a type III secretion system, where it becomes expressed on the cell surface $[21,22]$. Intimin binds to Tir leading to its activation, which results in actin polymerisation within the host cell and the formation of a pedestal, facilitating tighter adherence between the host cell and the bacterium $[17,23]$. Other eukaryotic receptors have been suggested for intimin, including nucleolin and some $\beta 1$ integrins, but as yet it is unknown if these interactions have a role in vivo [24,25].

There is considerable sequence variation between the intimins from different $E$. coli strains and they have been categorised into different subtypes, each with a high affinity for its own cognate Tir [26]. However, despite this diversity, it has been found that within the C-terminal binding domain there are four tryptophan residues and two cysteine residues, which are conserved between all subtypes $[27,28]$. The two cysteines are also conserved in similar locations within the $Y$. pseudotuberculosis invasin. In both invasin and intimin a disulphide bond is formed, which is essential for the structure of the C-terminal binding domain and therefore required for full functionality $[29,30]$. In the instance of invasin, disruption of either cysteine results in an inability to bind to integrin, and therefore is defective for invasion [29].

Analysis of $Y$. pseudotuberculosis strain IP32953 sequence data identified a gene encoding a protein with significant amino acid similarity to invasin and intimin, which has not been previously investigated. We have termed this protein Ifp (intimin family protein) and intriguingly it has been mutated to a pseudogene in all seven $Y$. pestis genomes sequenced to date. Examination of the amino acid sequence of Ifp revealed that three of the four tryptophans and both of the cysteine residues that are important in intimin function are conserved. However, no Tir orthologue can be identified in the IP32953 genome sequence. Given the amino acid similarity of Ifp to both invasin and intimin, coupled with it being putatively non-functional in $Y$. pestis, we postulated that Ifp may be an adhesin. We demonstrate that Ifp is a functional adhesin that binds to distinct foci on host cells. Expression occurs in late log or early stationary phase at $37^{\circ} \mathrm{C}$ only and coincides with a decline in the expression of invasin at this temperature.

\section{Methods}

\section{Strains used and culture conditions}

All $Y$. pseudotuberculosis strains were cultured in LuriaBertani (LB) broth Miller (BD Biosciences, Oxford, UK) or on LB agar (Novagen, Nottingham, UK) at $28^{\circ} \mathrm{C}$ unless otherwise stated. The retention of the virulence plasmid (pYV) was screened by plating $Y$. pseudotuberculosis strains on CRMOX plates [31]. Antibiotics were used at the following concentrations where appropriate, ampicillin $\left(100 \mu \mathrm{g} \mathrm{ml}^{-1}\right)$, kanamycin $\left(50 \mu \mathrm{g} \mathrm{ml}^{-1}\right)$, chloramphenicol $\left(30 \mu \mathrm{g} \mathrm{ml}^{-1}\right)$ and trimethoprim $\left(100 \mu \mathrm{g} \mathrm{ml}{ }^{-1}\right)$. E. coli strains were cultured at $37^{\circ} \mathrm{C}$ overnight in $\mathrm{LB}$ broth Miller or on LB agar unless otherwise stated. See table 1 for a list of the strains and plasmids used in this study.

\section{Construction of lux reporter strains}

PCR primers (Table 2) were designed to amplify $956 \mathrm{bp}$ and $636 \mathrm{bp}$ fragments between YPTB1572 and YPTB1573 and between YPTB1667 and YPTB1668 respectively using $Y$. pseudotuberculosis strain IP32953 genomic DNA as a template. These regions contain the putative promoter and regulatory sequences for ifp (YPTB1572) and inv (YPTB1668). These PCR products were cloned into the pGEM-T Easy vector (Promega, Southampton, UK). KpnI and SpeI restriction sites had

\section{Table 1 The strains and plasmids used in this study}

\begin{tabular}{ll}
\hline Strain or plasmid & Reference \\
\hline Y. pseudotuberculosis IP32953 & [3] \\
Y. pseudotuberculosis IP32953 $\triangle \mathrm{FFP}$ & This study \\
Y. pseudotuberculosis IP32953 $\triangle \mathrm{INV}$ & This study \\
Y. pseudotuberculosis IP32953 $\triangle \mathrm{IFP} \Delta \mathrm{NNV}$ & This study \\
Y. pseudotuberculosis IP32953 $\triangle \mathrm{IFPpIFP}$ & This study \\
Y. pseudotuberculosis IP32953 YPTB1572Lux & This study \\
Y. pseudotuberculosis IP32953 YPTB1668Lux & This study \\
E. coli TB1 MBP-Ifp & This study \\
E. coli TB1 MBP-IfPC337G & This study \\
\hline
\end{tabular}


Table 2 Primers used in this study

\begin{tabular}{|c|c|}
\hline Primer & Sequence \\
\hline YPTB1572Lux1 & TTCCCGGGCACCTTGGCTGCACCGACTTC \\
\hline YPTB1572Lux2 & TITGGTACCCGATAGAGACTCATACTTACC \\
\hline YPTB1668Lux1 & TाTCCCGGGCATTTGGGTGAACACAGAGG \\
\hline YPTB1668Lux2 & TाTGGTACCGAGAAACTCACTGATTGGCTG \\
\hline YptblntMBP-1 & TCAGAATTCATTAGTGAAGTCACCCCAAC \\
\hline YptblntMBP-2 & TCATCTAGATGTGCCAGAGCCCTCCTAACC \\
\hline YptblntMBP-3 & TCATCTAGATTTATITATACCCATGTAAAGC \\
\hline INTPROM3 & TIGGTACCTCAATTACATATCGTTAACGC \\
\hline INTPROM4 & TाGCATGCGATCTGTCTAAAGAGCGTCG \\
\hline INTA & TITGCATGCTGGAGTATAGGTAAGTATGAG \\
\hline INTB & TाTAGGCTCGTTGCACATCGGCTAATGG \\
\hline YPTB1668Chlor1 & CAGGTCCAGCCTTATTCTGTCTCTTCATCTGCATTTGAAAATCTCCATCCTCACTTATTCAGGCGTAGCAC \\
\hline YPTB1668Chlor4 & CGTTCTCCAATGTACGTATCCCGACGCCAAGGTTAAGTGTGTTGCGGCTGCATAGTAAGCCAGTATACACTC \\
\hline
\end{tabular}

Restriction sites are in bold and position of mutated cysteine to glycine residue is underlined.

been incorporated into the primer sequences to enable the luxCDABE operon from pBluelux [32] to be inserted downstream of each promoter region. The entire promoter-lux construct was excised from pGEM-T Easy then re-cloned into the pDM4 suicide plasmid using Transformax EC100D pir+ E. coli (Epicentre Biotechnologies, Madison, USA) for selection and screening. The resulting promoter fusions 1572lux and 1668lux in pDM4 were then electroporated into the IP32953 strain of $Y$. pseudotuberculosis and screened for single crossover event into the genome by chloramphenicol resistance. This crossover event resulted in a functional gene of interest, with the lux cassette with native promoter inserted upstream of the gene on the chromosome.

\section{Bioluminescence and optical density of Lux constructs}

Bioluminescence and optical density were monitored simultaneously in 96-well microtitre plates using the Anthos Lucy1 combined photometer and luminometer controlled by the Stingray software (Dazdaq). Overnight $30^{\circ} \mathrm{C}$ cultures of $1572 l u x$ and 1668lux were diluted 1:200 in fresh $\mathrm{LB}$ with antibiotics and grown for $3-4 \mathrm{~h}$ at $30^{\circ} \mathrm{C}$. The optical density of the culture was adjusted to a starting $\mathrm{OD}_{600}$ of 0.1 and $200 \mu \mathrm{l}$ was added to the wells of the 96 well plate. Assays were performed at $24^{\circ} \mathrm{C}, 28^{\circ} \mathrm{C}$ and $37^{\circ} \mathrm{C}$. Luminescence and OD at $405 \mathrm{~nm}$ of the cultures was automatically determined every $30 \mathrm{~min}$ for $18 \mathrm{~h}$ and presented as relative light units per unit of $\mathrm{OD}_{405}$ (light per unit cell). For every promoter fusion assay each sample was assayed in triplicate on the 96-well plate, and each experiment was carried out in duplicate.

\section{Construction of Maltose Binding Protein (MBP) fusion proteins}

Primers YptbIntMBP-1 and YptbIntMBP-2 (Table 2) were used to PCR amplify the 3 ' end (1044 bp) of the ifp coding sequence. This PCR product was cloned into the pMAL-p2x vector (NEB, Hitchin, UK) using EcoRI and $X b a I$ enzyme restriction sites which had been incorporated into the primer design. In order to generate an MBP-Ifp fusion with the terminal cysteine (Cys1070) mutated to a glycine $\left(\mathrm{MBP}-\mathrm{Ifp}_{\mathrm{C} 337 \mathrm{G}}\right)$, primer YptbIntMBP-3 was substituted for YptbMBP-2. Primer YptbIntMBP-3 contained an alternative sequence (underlined in table 2) to mutate the terminal cysteine to a glycine. MBP-fusion proteins were then expressed in TB1 E. coli.

\section{Purification of MBP-Ifp and MBP-Iff ${ }_{\mathrm{C} 337 \mathrm{G}}$}

E. coli transformed with the MBP-fusion plasmids were cultured for $2 \mathrm{~h}$ at $37^{\circ} \mathrm{C}$ using $5 \mathrm{ml}$ of an overnight culture in $250 \mathrm{ml} \mathrm{LB}$ broth with $2 \mathrm{mM}$ glucose and ampicillin until a culture growth of $\mathrm{OD}_{600} 0.5$ was reached. Expression of the fusion protein was induced with 0.3 $\mathrm{mM}$ isopropyl- $\beta$-D-thiogalactoside (IPTG) then the culture was incubated for further 2 hours at $37^{\circ} \mathrm{C}$. The cultures were centrifuged and pellets stored overnight at $-20^{\circ} \mathrm{C}$ then resuspended in column buffer $(20 \mathrm{mM}$ Tris$\mathrm{HCl}, 200 \mathrm{mM} \mathrm{NaCl}, 1 \mathrm{mM}$ EDTA in $\mathrm{H}_{2} \mathrm{O}$ ). The cells were lysed by sonication using a Bioruptor sonicator (Diagenode; 60 second pulses with a 30 second recovery period). Insoluble proteins were removed by centrifugation and the supernatant was applied to $1 \mathrm{ml}$ columns of amylose resin (NEB). After washing with $15 \mathrm{ml}$ column buffer, proteins were eluted with $10 \mathrm{ml}$ column buffer/10 mM maltose. Proteins were concentrated using Amicon ultra $50 \mathrm{kDa}$ columns (Millipore, Watford, UK), and then confirmed by Coomassie staining and western blotting with anti-MBP (NEB). Protein concentrations were determined by Pierce BCA protein assay kit (Rockford, USA) according to the manufacturer's protocol. 


\section{Analysis of MBP-fusion protein binding to HEp-2 cells by fluorescence microscopy}

Binding of MBP-tagged Ifp was determined by fluorescence microscopy as described previously [18]. HEp-2 cells were cultured overnight on glass coverslips in 24well plates at $2.5 \times 10^{5}$ cells/well in $1 \mathrm{ml}$ tissue culture media (minimum essential medium eagle (MEM), 10\% fetal calf serum (w/v), $2 \mathrm{mM}$ L-glutamine, $100 \mathrm{U}$ penicillin $\mathrm{ml}^{-1}, 100 \mu \mathrm{g}$ streptomycin $\mathrm{ml}^{-1}$, MEM non-essential amino acids). The cells were blocked for 30 minutes at $37^{\circ} \mathrm{C} / 5 \% \mathrm{CO}_{2}$ in $250 \mu \mathrm{l}$ binding solution (0.4\% BSA (w/v), $2.5 \mathrm{mM}$ maltose, $2 \mathrm{mM}$ L-glutamine in RPMI media), then incubated for 45 minutes at $37^{\circ}$ $\mathrm{C} / 5 \% \mathrm{CO}_{2}$ with $250 \mu \mathrm{l}$ MBP-Ifp, MBP-Ifp ${ }_{\mathrm{C} 337 \mathrm{G}}$ or $\mathrm{MBP}$ protein alone (NEB) at $100 \mu \mathrm{g} \mathrm{ml}^{-1}$ in binding solution. The cells were washed 5 times with $1 \mathrm{ml}$ $\mathrm{PBS} / 1 \% \mathrm{BSA}(\mathrm{w} / \mathrm{v})$ and incubated for 30 minutes at $37^{\circ} \mathrm{C} / 5 \% \mathrm{CO}_{2}$ in $250 \mu \mathrm{l}$ of a $1: 1000$ dilution of rabbit anti-MBP antibody (NEB) in binding solution used. Cells were washed 5 times with $1 \mathrm{ml}$ PBS/1\% BSA (w/ v) and incubated for 30 minutes at $37^{\circ} \mathrm{C} / 5 \% \mathrm{CO}_{2}$ in $250 \mu \mathrm{l}$ of a 1:1000 dilution of goat anti-rabbit IgG Alexafluor 488 (Invitrogen) in binding solution. Cells were washed 4 times with $1 \mathrm{ml} \mathrm{PBS} / 1 \% \mathrm{BSA}(\mathrm{w} / \mathrm{v})$ and fixed for 15 minutes at $-20^{\circ} \mathrm{C}$ in $250 \mu \mathrm{l}$ of $95 \%$ ethanol-5\% acetic acid (v/v). The cover slips were removed from the wells, washed in Milli Q $\mathrm{H}_{2} \mathrm{O}$ and mounted onto glass slides with Vectashield-DAPI (Vector Laboratories, Peterborough, UK) mounting medium. The coverslips were examined using an Axiovert 200M (Zeiss, Welwyn Garden City, UK) confocal microscope. Experiment was performed on three independent occasions and at least 50 cells were examined per experiment.

\section{FACScan analysis of MBP-fusion protein binding to HEp-2 cells}

A similar methodology was used as for the fluorescence microscopy as described previously [18], with the following modifications. The cells were grown directly in 6 -well plates at $7 \times 10^{5}$ cells/well. The Alexafluor 488 anti-rabbit IgG antibody was diluted to $1: 5000$ in PBS/ $1 \%$ BSA $(w / v)$. Cells were resuspended in PBS $/ 0.5 \%$ EDTA (w/v) and transferred to BD Falcon $5 \mathrm{ml}$ tubes (VWR, Lutterworth, UK). Cells were washed once with $\mathrm{PBS} / 1 \% \mathrm{BSA}(\mathrm{w} / \mathrm{v})$ and centrifuged, then were fixed for 5 minutes on ice in $2 \%$ paraformaldehyde/PBS (w/v). The cells were washed once with PBS/1\% BSA (w/v), centrifuged and then were resuspended in $500 \mu \mathrm{l}$ PBS/ $1 \%$ BSA $/ 0.02 \%$ EDTA (w/v). The fluorescence was measured using a FACScan machine (Becton Dickinson, Oxford, UK). Experiment was performed on two independent occasions and 20,000 cells were examined for fluorescence from each sample.

\section{Analysis of co-localisation of MBP-fusion protein and the receptors CD59 and $\beta 1$ integrin on $\mathrm{HEp}-2$ cells by fluorescence microscopy}

A similar methodology was used as for the fluorescence microscopy described above with the following modifications. After the MBP-fusion protein incubation the cells were washed 5 times with PBS then incubated with $250 \mu \mathrm{l}$ of a 1:20 dilution rabbit anti-Ifp (CovalAb, this study) and 1:1000 dilution of mouse anti-CD59 (Invitrogen) or a 1:1000 dilution of mouse anti- $\beta 1$ integrin in binding solution for 30 minutes at $37^{\circ} \mathrm{C} / 5 \% \mathrm{CO}_{2}$. The cells were washed 5 times with $1 \mathrm{ml}$ PBS then incubated with $250 \mu \mathrm{l}$ of a 1:1000 dilution of goat anti-rabbit IgG Alexafluor 594 (Invitrogen) and 1:1000 dilution of goat anti-mouse IgG Alexafluor 488 (Invitrogen) for $30 \mathrm{~min}$ utes at $37^{\circ} \mathrm{C} / 5 \% \mathrm{CO}_{2}$. The cells were washed 5 times with $1 \mathrm{ml}$ PBS then fixed for 30 minutes at $4{ }^{\circ} \mathrm{C}$ with $250 \mu \mathrm{l} 2 \%$ paraformaldehyde (w/v). The coverslips were removed from the wells, washed with PBS then mounted onto glass slides with Vectashield-DAPI mounting medium (Vector Laboratories). The slides were examined using an Axiovert $200 \mathrm{M}$ confocal microscope (Zeiss). At least three areas of approximately 10 cells each were examined per sample and the experiment was performed on three independent occasions.

\section{Construction of ifp and inv insertional mutants}

An ifp knockout mutant was generated in the $Y$. pseudotuberculosis strain IP32953, after initially constructing an ifp mutant in strain YPIII. Briefly, $1725 \mathrm{bp}$ of ifp was amplified with IntA and IntB primers, digested with $S a c$ I and SphI then ligated into the cloning vector pGEM-T easy. The plasmid was digested with BglII to linearise and allow for the ligation of the kanamycin cassette within the ifp sequence. PCR with primers IntA and IntB was undertaken on the plasmid to create linear fragments of kanamycin cassette flanked by ifp sequence. This PCR product was electroporated into YPIII previously transformed with $\mathrm{pKOBEG}$, which contains the $\lambda$ red recombinase operon. The temperature sensitive pKOBEG plasmid was then lost from putative mutants by growth at $37^{\circ} \mathrm{C}$, whilst the presence of the pYV plasmid was maintained by the addition of $2.5 \mathrm{mM}$ $\mathrm{CaCl} 2$. Southern blot analysis confirmed correct mutation. Genomic DNA from this YPIII $\Delta$ ifp was used as a template for PCR amplification of the kanamycin cassette flanked by two $\sim 500$ bp regions of gene-specific DNA. The primers INTA and INTB (Table 2) were used to amplify a $2.7 \mathrm{kbp}$ product. This was purified using a Qiagen PCR purification kit, precipitated, and then resuspended in $5 \mu$ MilliQ $\mathrm{H}_{2} \mathrm{O}$. Strain IP32953 containing the mutagenesis plasmid pAJD434 [33] was grown in LB broth containing $100 \mu \mathrm{g}$ trimethoprim $\mathrm{ml}^{-1}$ and $0.8 \%$ arabinose $(\mathrm{w} / \mathrm{v})$ for 5 hours at $28^{\circ} \mathrm{C}$ in order to 
induce the expression of the $\lambda$-red genes from the pAJD434 plasmid. These cells were electroporated with the purified PCR product and kanamycin resistant colonies were screened by PCR and Southern blot to confirm the correct insertion. The pAJD434 plasmid was then removed by incubation overnight at $37^{\circ} \mathrm{C}$ in the presence of $2.5 \mathrm{mM} \mathrm{CaCl}_{2}$. Colonies were screened to confirm the loss of the pAJD434 plasmid and the presence of the virulence plasmid (pYV). A similar method was used for the construction of the inv mutant except primers YPTB1668Chlor1 and YPTB1668Chlor4 (Table 2 ), were designed to amplify the chloramphenicol resistant cassette from pBAD33 flanked by 50 bp gene-specific regions. This PCR product was then used as described above to generate an insertional mutant of the inv gene (IP $\triangle \mathrm{INV}$ ) and a double ifp and inv insertional mutant (IP $\triangle$ IFP $\triangle$ INV), by electroporation into IP32953 WT or mutated ifp (IP $\triangle$ IFP) strains. Colonies were screened as above with inv specific primers and the presence of pYV and loss of pAJD434 was confirmed.

\section{Construction of ifp complement in pBAD33 plasmid}

The ifp gene including native promoter was amplified by PCR using specific primers INTPROM3 + INTPROM4 (Table 2). After ligation into pGEM-T Easy vector (Promega) the construct was transformed into XL2-Blue $E$. coli (Stratagene, La Jolla, USA). The construct was screened by PCR and sequenced, before the ifp gene with promoter was digested from the pGEM-T Easy vector with $K p n \mathrm{I}$ and $S p h \mathrm{I}$ and purified by gel extraction using a Gen Elute purification kit (Sigma). This insert was cloned into a pBAD33 plasmid [34], also digested with KpnI and SphI and transformed into TOP10 E. coli (Invitrogen). These colonies were again screened by PCR and by digestion with EcoRV to confirm the correct insert and orientation within the pBAD33 vector. IP $\triangle$ IFP cells were made competent by washing 3 times in $10 \mathrm{ml}$ ice cold $\mathrm{H}_{2} \mathrm{O}$ and electroporated with pBAD33ifp (pIFP) plasmid to generate an ifp mutant with a complemented ifp gene (IP $\triangle$ IFPpIFP). These were screened by PCR and were DNA sequenced again to confirm the presence of the correct complemented gene.

\section{Plasmid cured strains}

Wild type, defined mutants and ifp complemented mutant strains lacking the pYV plasmid were generated by culturing strains overnight at $37^{\circ} \mathrm{C}$ the selecting for white colonies on CRMOX plates [31]. Loss of pYV was verified by PCR and repeated screening on CRMOX.

\section{Adhesion and invasion of HEp-2 cells}

$\mathrm{HEp}-2$ cells were cultured overnight at $37^{\circ} \mathrm{C} 5 \% \mathrm{CO}_{2}$ on coverslips in 24-well plates at $2 \times 10^{5}$ cells/well in $1 \mathrm{ml}$ tissue culture medium. The $10 \mathrm{ml} \mathrm{LB}$ broth cultures of
IP32953 wild type (IPWT), defined mutants (IP $\Delta$ IFP, IP $\triangle$ INV, IP $\triangle$ IFP $\triangle$ INV) and mutant with complemented ifp (IP $\triangle$ IFPpIFP), were incubated at $37^{\circ} \mathrm{C}$ for 14 hours with appropriate antibiotics and $2.5 \mathrm{mM} \mathrm{CaCl}_{2}$. The cells were washed 3 times with $1 \mathrm{ml}$ PBS and then, at a multiplicity of infection (MOI) of 70:1, incubated for 1 hour with $1 \mathrm{ml}$ of bacterial culture in MEM media at $37^{\circ} \mathrm{C}, 5 \% \mathrm{CO}_{2}$. Inoculum was plated on $\mathrm{LB}$ agar to determine number of colony forming units (cfu). The cells were washed 5 times with $1 \mathrm{ml}$ PBS and then fixed with $2 \%$ paraformaldehyde $(\mathrm{w} / \mathrm{v})$ for 45 minutes at $4^{\circ} \mathrm{C}$, before being washed again 5 times with $1 \mathrm{ml}$ PBS. The coverslips were incubated with a 1:500 dilution of antiYersinia pseudotuberculosis antibody (Abcam, Cambridge, UK) in PBS for 45 minutes at room temperature. The coverslips were washed with PBS then incubated with a 1:1000 dilution of anti-rabbit IgG Alexafluor 488 (green) (Invitrogen) in PBS for 45 minutes at room temperature. After washing with PBS the cells were permeabilised with $0.1 \%$ Triton X100-PBS (v/v) for 20 minutes at room temperature. The coverslips were washed with PBS and incubated with 1:500 dilution of anti-Y. pseudotuberculosis antibody (Abcam) in PBS for 45 minutes at room temperature, before being washed again with PBS. Anti-rabbit IgG Alexafluor 594 (red) (Invitrogen) was diluted 1:1000 in PBS and the coverslips were incubated for 45 minutes at room temperature. The coverslips were washed with PBS and mounted onto slides with Vectorshield-DAPI mounting media (Vector Laboratories). Slides were examined by Axiovert 200 M (Zeiss) confocal microscope. Three coverslips per strain with 100 HEp-2 cells per coverslip were counted, utilising the z stack images to gain a 3D representation of the cell. Adhesion and invasion were quantified by counting invaded (red) and adhered (red/green) bacteria and calculating percentage adhesion or invasion per HEp-2 cell based on known MOI. This adhesion and invasion assay was performed on at least three independent occasions.

\section{Detection of the presence of invasin by western blot}

Strains were cultured for 15 hours at $28^{\circ} \mathrm{C}$ and $37^{\circ} \mathrm{C}$, the $\mathrm{OD}_{600 \mathrm{~nm}}$ measured and cultures adjusted so all strains had equal quantities of bacteria/ml. Strains were run on a SDS-PAGE $12 \%$ Bis-Tris gel, blotted onto nitrocellulose membrane and blocked with $5 \%$ milk-PBS-0.1\% Tween20. Invasin was visualised by staining with antiinvasin monoclonal antibody [35] at 1:10000 and antirabbit IgG peroxidase conjugate (Sigma) secondary antibody at 1:10000.

\section{Galleria mellonella model of infection}

G. mellonella larvae were purchased from Livefood UK Ltd (Rooks Bridge, Somerset, UK). Larvae were infected with $10^{6} \mathrm{cfu} Y$. pseudotuberculosis IP32953WT, IPAIFP, 
IP $\triangle \mathrm{INV}, \mathrm{IP} \Delta \mathrm{IFP} \Delta \mathrm{INV}$ or IP $\Delta$ IFPpIFP in $10 \mu \mathrm{l}$ inocula by micro-injection ( $25 \mu \mathrm{l}$ Hamilton syringe, Cole Palmer, London, UK) in the right foremost leg. PBS and no injection controls were used. The larvae were incubated at $37^{\circ} \mathrm{C}$ and survival at 72 hours post-infection was recorded. Larvae were scored as dead when the colouration changed from normal pale cream to brown and failed to respond even after gentle manipulation with a pipette tip.

\section{Results}

Identification of an intimin and invasin-like protein in $Y$. pseudotuberculosis

The genome sequence of $Y$. pestis strain CO92 first revealed the potential presence of an intimin-like protein [36]. However, in this sequence and all other subsequently sequenced $Y$. pestis strains, the predicted coding sequence for the intimin-like protein is disrupted by an IS285 element, or in the instance of strain 91001, a premature stop codon. By contrast, this gene is intact in all four $Y$. pseudotuberculosis strains sequenced to date, with at maximum, only six amino acid differences between these strains (Additional file 1). Alignments with the European Bioinformatics Institute (EBI) EMBOSS Pairwise Alignment tool [37] revealed that the translated full-length coding sequence of IP32953 Ifp has $33.9 \%$ amino acid identity (or 46.7\% similarity) to $Y$. pseudotuberculosis IP32953 invasin, and $29.7 \%$ amino acid identity (42.8\% similarity) to the $\alpha$ subtype of intimin (eaeA) from E2348/69 E. coli, therefore this gene was termed ifp. Using the ClustalW program (SDSC Workbench, San Diego, USA) alignment of the C terminal domains of invasin, intimin and Ifp, reveals the presence of two cysteine residues in Ifp, which are important for the function of invasin and intimin (Figure 1). In addition three of the four tryptophans, which are present in all intimin subtypes [27], are also present in Ifp and invasin (Figure 1).

\section{Thermoregulated temporal expression of ifp and inv}

The expression of ifp (YPTB1572) and inv (YPTB1668) at $24^{\circ} \mathrm{C}, 28^{\circ} \mathrm{C}$ and $37^{\circ} \mathrm{C}$, were monitored using lux -based promoter fusions 1572lux and 1668lux in Y. pseudotuberculosis IP32953, with the resultant luminescence read in a Lucyl combined photometer and luminometer (Figure 2). The expression was determined as relative light units/optical density (RLU/OD) therefore the growth phase could also be determined, based on these OD readings (Additional file 2). Inv was maximally expressed during $\log$ phase after 5 hours at $24^{\circ} \mathrm{C}$ and $28^{\circ} \mathrm{C}$, but after only 2.5 hours at $37^{\circ} \mathrm{C}$, suggesting that mammalian body temperature is important in the induction of inv and confirms the observation of Isberg et al. [38]. In contrast, ifp expression remains low at $24^{\circ} \mathrm{C}$ and $28^{\circ} \mathrm{C}$ throughout the time course, whereas at $37^{\circ} \mathrm{C}$ there was little expression in first 7.5 hours, after which expression increases to a peak at 13 hours (Figure 2).

\section{Ifp binds to localised foci on HEp-2 cells}

Invasin and intimin are able to bind directly to specific receptors on the surface of mammalian cells. We therefore investigated the ability of Ifp to bind directly to HEp-2 cells using a MBP tagged Ifp purified protein (MBP-Ifp). In addition, to determine if the terminal cysteine was as important in Ifp functionality (as it is in invasin and intimin), a MBP-Ifp recombinant protein with the terminal cysteine mutated to a glycine (MBPIf $_{\text {C337G }}$ ) was constructed and tested. Utilising flow cytometry, FACScan analysis showed a shift in the peak of fluorescence of HEp-2 cells which had been incubated with MBP-Ifp (Figure 3). This shift was not seen

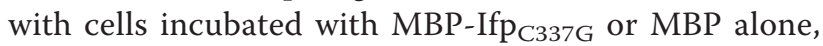
indicating not only that this is a specific binding of MBP-Ifp, but also that the terminal cysteine is important in the functional binding of Ifp to HEp-2 cells. However, MBP-Ifp only appears to bind to a subset of cells and to differing levels, as shown by the width of the shifted peak. In order to investigate this further, we used confocal microscopy to visualise the binding of MBP-Ifp to HEp-2 cells (Figure 4). Again no specific binding is seen with the MBP control and binding is greatly reduced with MBP-Ifp ${ }_{\mathrm{C} 337 \mathrm{G}}$, whilst the MBP-Ifp fusion protein binds to individual cells with significant levels of fluorescence visible. Of 50 cells examined $\sim 40 \%$ showed MBP-Ifp adherence, with only $\sim 15 \%$ showing MBP-Ifp ${ }_{\mathrm{C} 337 \mathrm{G}}$ adhesion. Of those showing MBP-Ifp C337G $_{\text {G }}$ adherence, fewer fluorescing spots were observed per cell compared to MBP-Ifp, and these spots were smaller.

Interestingly, this binding appears to be localised to specific foci on the cell surface, rather than a random scattering of fluorescence across the entire cell surface. This suggests that the protein is binding to specific receptors on the cell surface which are localised in foci. In order to investigate if a putative receptor was localised in cholesterol and sphingolipid-enriched plasma membrane micro-domains (lipid rafts), we used co-localisation assays. In this instance the GPI-anchored protein CD59, which is known to localise to these microdomains [39], was used as a marker for the position of the lipid rafts. Confocal microscopy revealed that there is co-localisation between CD59 and MBP-Ifp bound on the cell surface, indicating that there is a putative receptor for Ifp present within these lipid rafts (Figure 5A). However, as there is binding of MBP-Ifp which does not co-localise, and as invasin is known to bind to $\beta 1$ integrin, co-localisation between MBP-Ifp and $\beta 1$ integrin was also investigated (Figure $5 \mathrm{~B}$ ). No co-localisation was observed between MBP-Ifp and $\beta 1$ integrin. 


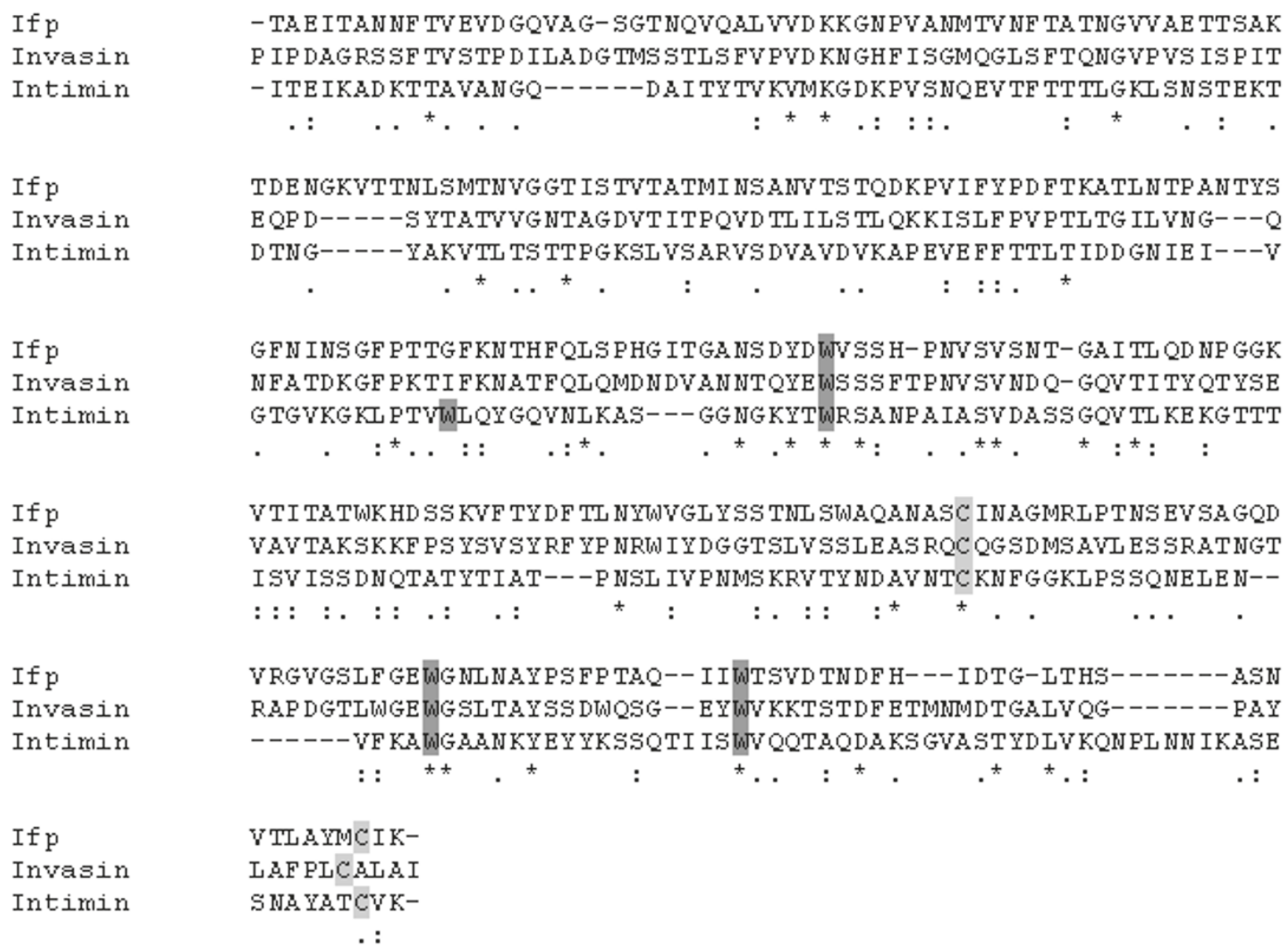

Figure 1 Amino acid alignment of intimin, ifp and invasion. The C-terminal 280 residues of EPEC 2348/69 intimin (Int280) and the corresponding regions from Y. pseudotuberculosis IP32953 Ifp and invasin were aligned. Residues important in intimin function are shown: conserved cysteine residues are highlighted in light grey whilst tryptophan residues are highlighted in dark grey.

\section{Adhesion and invasion assays}

In order to confirm the role of Ifp as an adhesin, we constructed an insertion mutant in the ifp coding sequence of $Y$. pseudotuberculosis strain IP32953 (IP $\triangle I F P)$. For comparative purposes, we also constructed an insertion mutant in the inv gene (IP $\Delta \mathrm{INV}$ ), and a double insertion mutant (IP $\triangle$ IFP $\triangle I N V)$ in the same strain. To determine the level of adhesion and invasion of these defined mutants, in comparison to wild type, a differential staining assay [40] was utilised. Figure 6 shows that there is a significant decrease in the level of adhesion of IPAIFP compared to wild type (IPWT), which could be restored by complementation with the wild type ifp gene (IP $\triangle$ IFPpIFP) (Figure 6A). The inv mutant did not show as great a reduction in adhesion as IP $\triangle$ IFP, but the double mutant showed comparable levels to the ifp single mutant. A significant decrease in invasion of IP $\triangle$ IFP compared to wild type is observed (Figure 6B). Both IP $\triangle \mathrm{INV}$ and
IP $\triangle$ IFP $\triangle$ INV show significant decreases in invasion compared to wild type; however, it was beyond the sensitivity of this assay to determine slight differences between these two strains. The average ratio of intracellular:extracellular bacteria for each of the strains associated with the HEp-2 cells was as follows; IPWT 1:8; IP $\Delta$ IFP 1:8; IP $\Delta$ INV 1:176; IP $\Delta$ IFP $\Delta$ INV 1:141 and IP $\triangle$ IFPpIFP 1:8. To determine the role of the virulence factors of the pYV in the adhesion and invasion still seen in these assays, the strains were cured of the pYV plasmid and the differential staining assay repeated (Figure 6C). Invasion levels were all below the sensitivity of this assay, but a significant difference was observed between wild type and IP $\triangle$ IFP, IP $\triangle$ INV and IP $\triangle$ IFP $\triangle I N V$ for adhesion. Although the expression analysis suggested the invasin should not be expressed at the time point used for these experiments, as there was a significant difference between wild type and inv mutants, presence of invasin was examined by western 


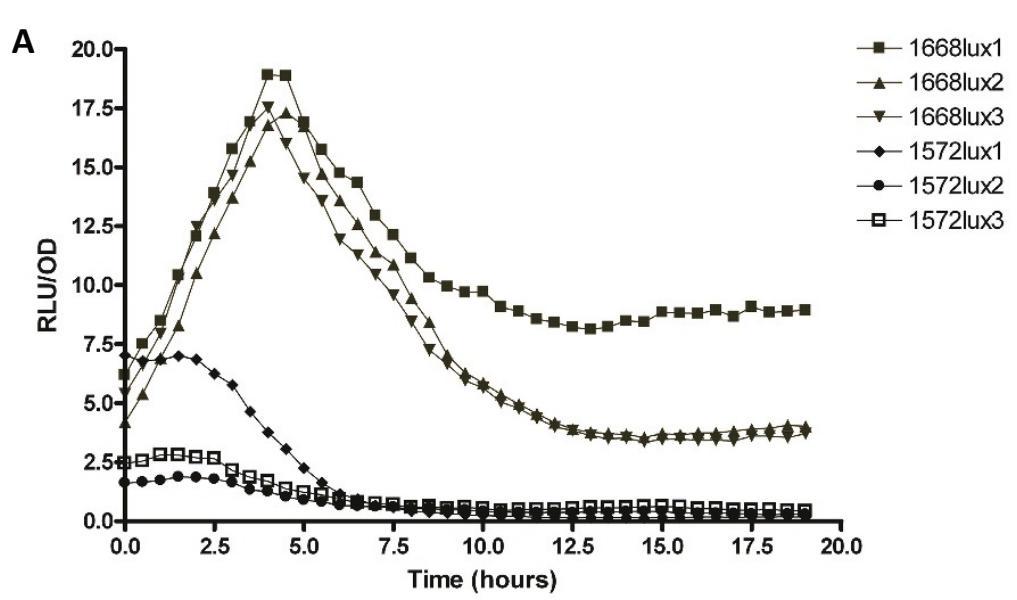

B
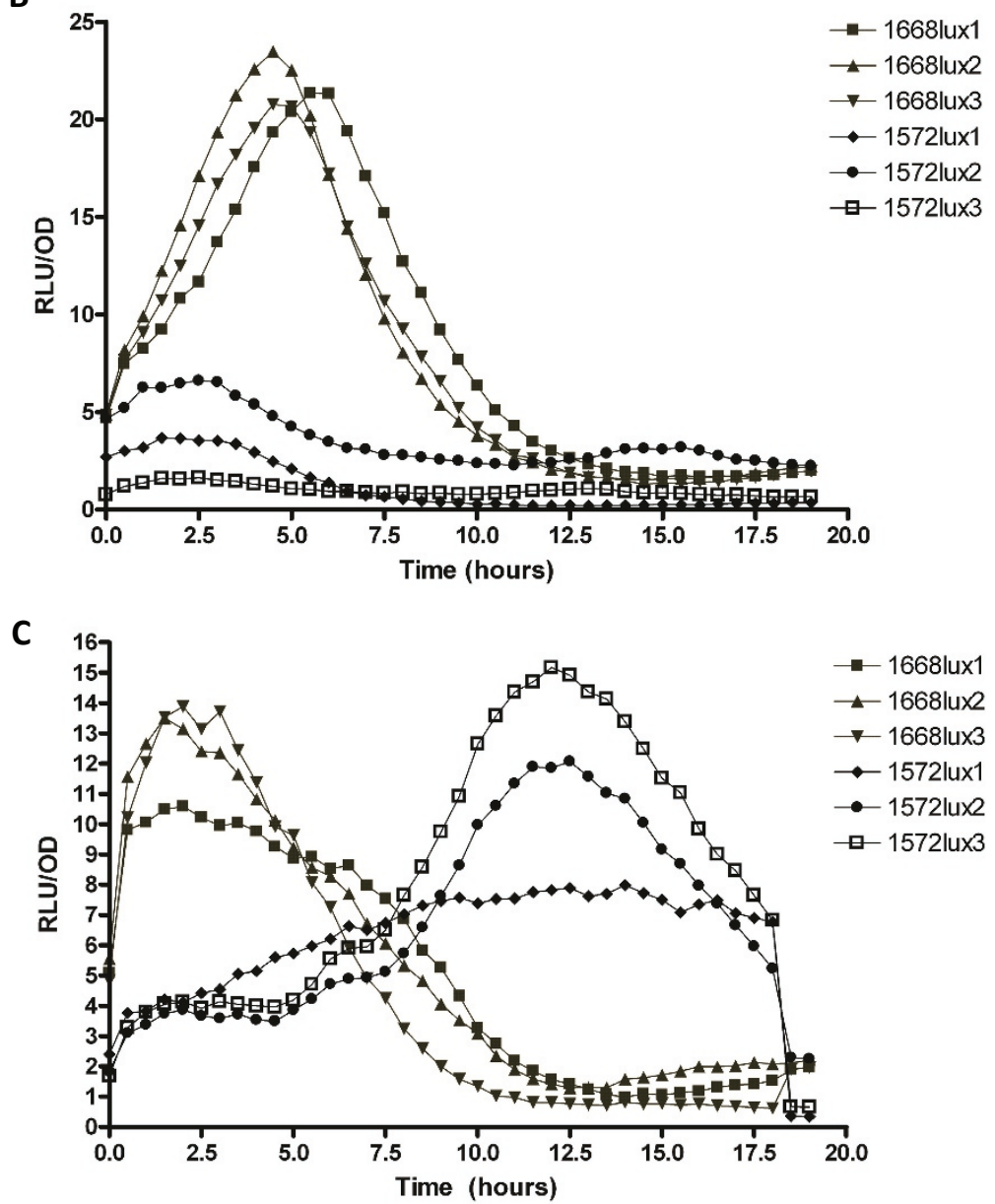

Figure 2 Temporal expression of ifp (1572/ux) and inv (1668/ux). Expression was determined by light emission from lux-reporter strains grown at (A) $24^{\circ} \mathrm{C},(B) 28^{\circ} \mathrm{C}$ and (C) $37^{\circ} \mathrm{C}$. Three biological replicates are shown for each strain, with each biological replicate tested in triplicate.

blot (Figure 6D). Invasin was found to still be present at $37^{\circ} \mathrm{C}$ although at a reduced level compared to $28^{\circ} \mathrm{C}$ 15 hour cultures. No invasin was observed in IP $\Delta \mathrm{INV}$ and IP $\triangle \mathrm{IFP} \triangle \mathrm{INV}$ which confirms the mutation of the inv gene in these strains.

\section{Galleria model of infection}

Galleria mellonella has been used as an infection model for several bacterial pathogens because it possesses an innate immune system with structural and functional homology to the mammalian immune system. Consequently it can be 

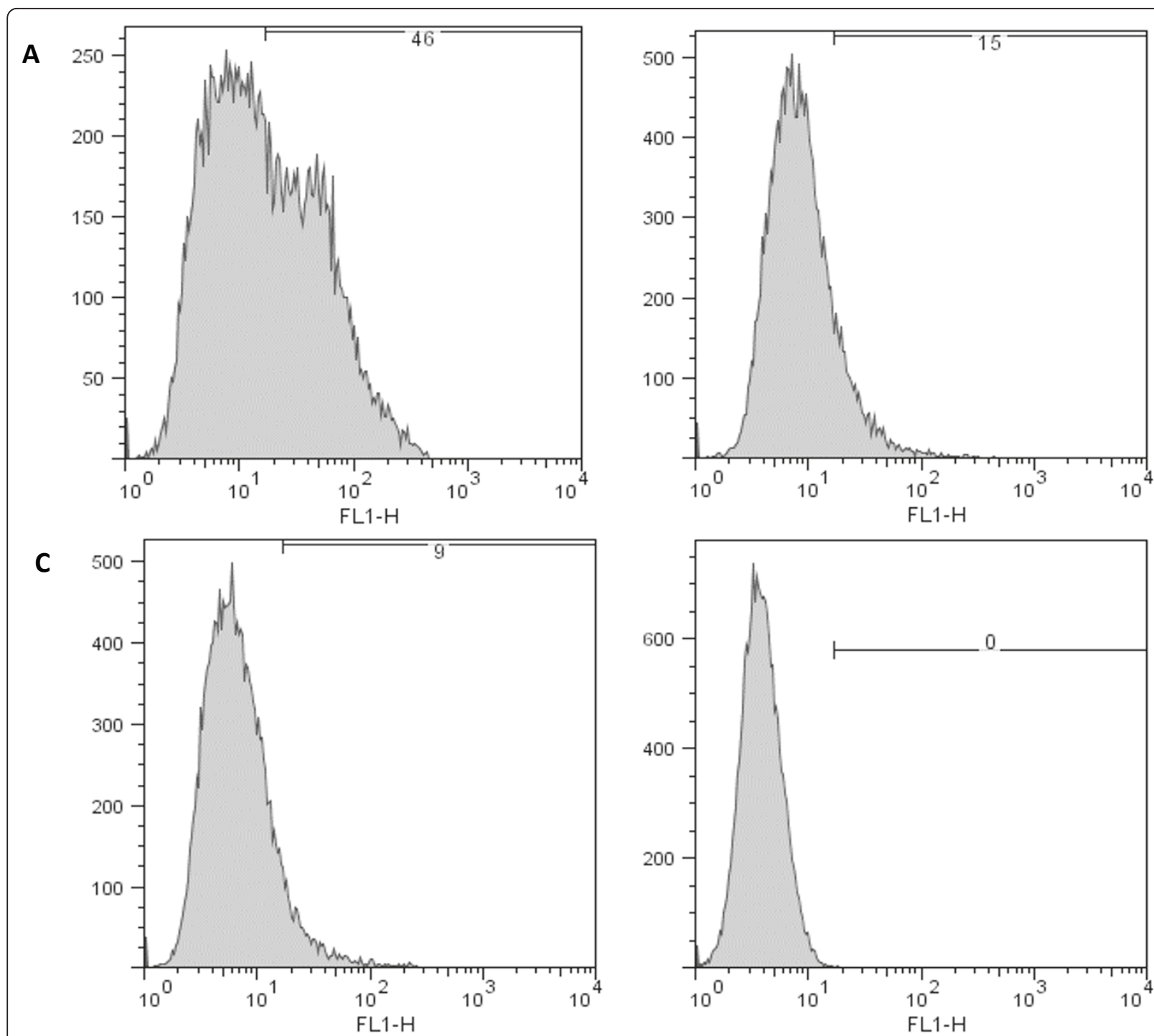

D

Figure 3 FACScan analysis of the binding of purified MBP-fusion proteins to HEp-2 cells. Cells were incubated with (A) MBP-Ifp, (B) MBPIfp $_{\mathrm{C} 337 \mathrm{G}}$ (C) MBP or (D) PBS and binding was visualised with anti-MBP and anti-rabbit Alexafluor 488 antibodies.

utilised as a less labour intensive and more cost effective model, in comparison to the traditional murine model of in vivo infection [41]. This model has been used recently for infection studies with $Y$. pseudotuberculosis [42]. Therefore, in addition to the adhesion and invasion assays, the ability of the mutants to infect and kill the wax moth larvae G. mellonella was examined. Bacteria, which had been cultured overnight at $37^{\circ} \mathrm{C}$, were injected into the foreleg of the G. mellonella at $10^{6}$ colony forming units (cfu) per 10 $\mu \mathrm{l}$ injection. After 72 hours at $37^{\circ} \mathrm{C}$ the number of dead $G$. mellonella were enumerated (Figure 7); larvae were scored as dead if they had become melanised and ceased moving [42]. Both IP $\triangle$ IFP (average 58\% survival, $\mathrm{p}=0.057$ ) and IP $\triangle$ INV (average $48 \%$ survival, $\mathrm{p}=0.200$ ) mutants showed modest if not significant attenuation in the G. mellonella model, compared to wild type IP32953 (average 30\% survival). IP $\triangle$ IFPpIFP shows similar levels of virulence to IPWT (average $30 \%$ survival, $\mathrm{p}=0.857$ ). Average survival of $75 \%$ was recorded in larvae infected with the double mutant, which showed a significant difference to the wild type ( $\mathrm{p}=$ 0.028 ) when analysed by non-parametric t-test (Graphpad Prism 4, La Jolla, USA).

\section{Discussion}

In this study we investigated the role of a novel $Y$. pseudotuberculosis adhesin (Ifp), which shows similarity to both invasin and the intimin adhesin of EPEC and EHEC (Figure 1). As invasin and intimin are well characterised virulence determinants, the discovery of a new member in the same family of outer membrane 


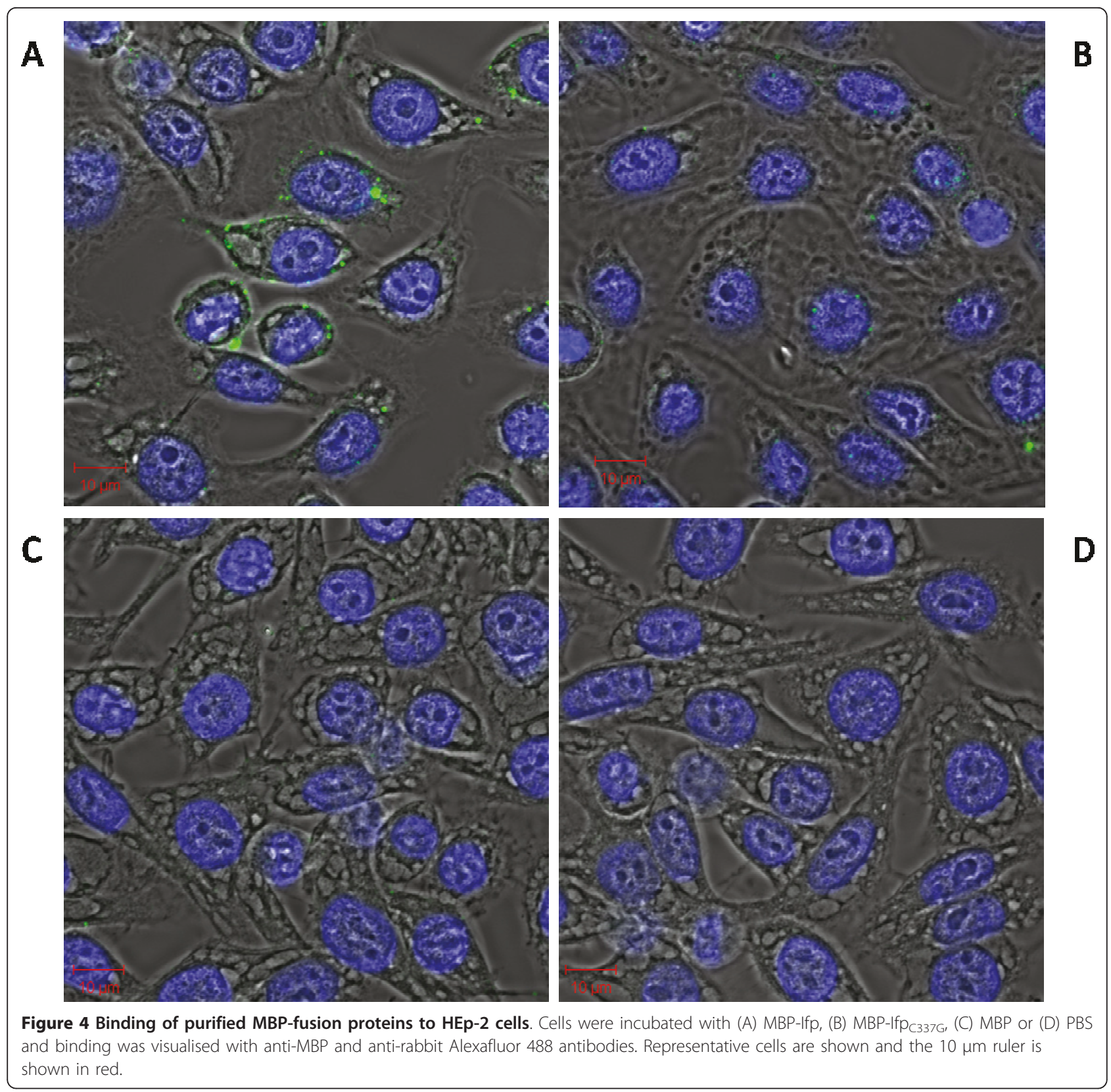

adhesins, is intriguing. The predicted coding sequence for ifp is disrupted in all seven currently sequenced strains of $Y$. pestis, although it is intact in the four $Y$. pseudotuberculosis strains sequenced. This disruption is due to an insertion element (IS285) in all Y. pestis strains, with the exception of the atypical $91001 Y$. pestis Microtus strain, where it is disrupted by a nonsense mutation $[3,43,44]$. This may suggest that the disruption in this gene in $Y$. pestis occurred early in the divergence of $Y$. pestis from $Y$. pseudotuberculosis and may have been a potentially important step in this evolutionary process. The inv gene of $Y$. pseudotuberculosis is also disrupted by an insertion element (IS200) in $Y$. pestis [45]. The reason for the loss of function of invasin and Ifp in $Y$. pestis is unknown, but given that it does not have an enteric phase in its lifecycle, it is likely to be not required. This follows the "use it or lose it" concept, whereby genes which no longer provide a selective advantage to the bacteria become pseudogenes [46]. The amino acid similarity of Ifp to both invasin and intimin, coupled with its retention in $Y$. pseudotuberculosis, suggests a putative role for Ifp in adhesion to cells and that Ifp is a new member in the family of surface adhesins together with invasin and intimin. 


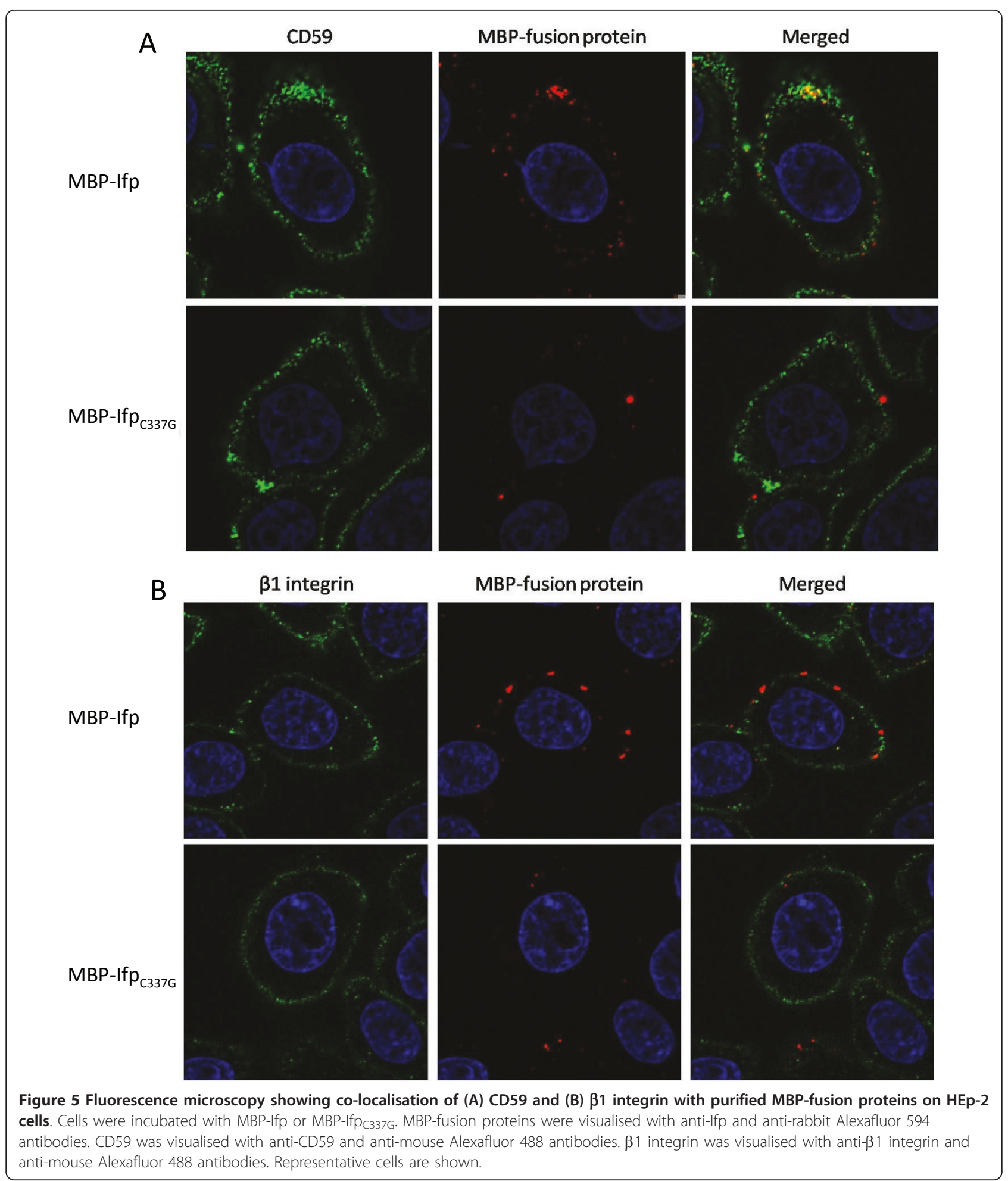

The C-terminal 280 amino acids of intimin are the functional domain in this adhesin [28], and two cysteine (C859 and C937; numbering according to EPEC strain E2348/69) and four tryptophan (W776, W795, W881 and W899) residues are conserved between all intimin subtypes. An alignment of the Cterminal region amino acid sequences of $\alpha$-subtype intimin from EPEC, Y. pseudotuberculosis invasin and Ifp, revealed that both cysteine and three out of the four tryptophan residues were found to be conserved 


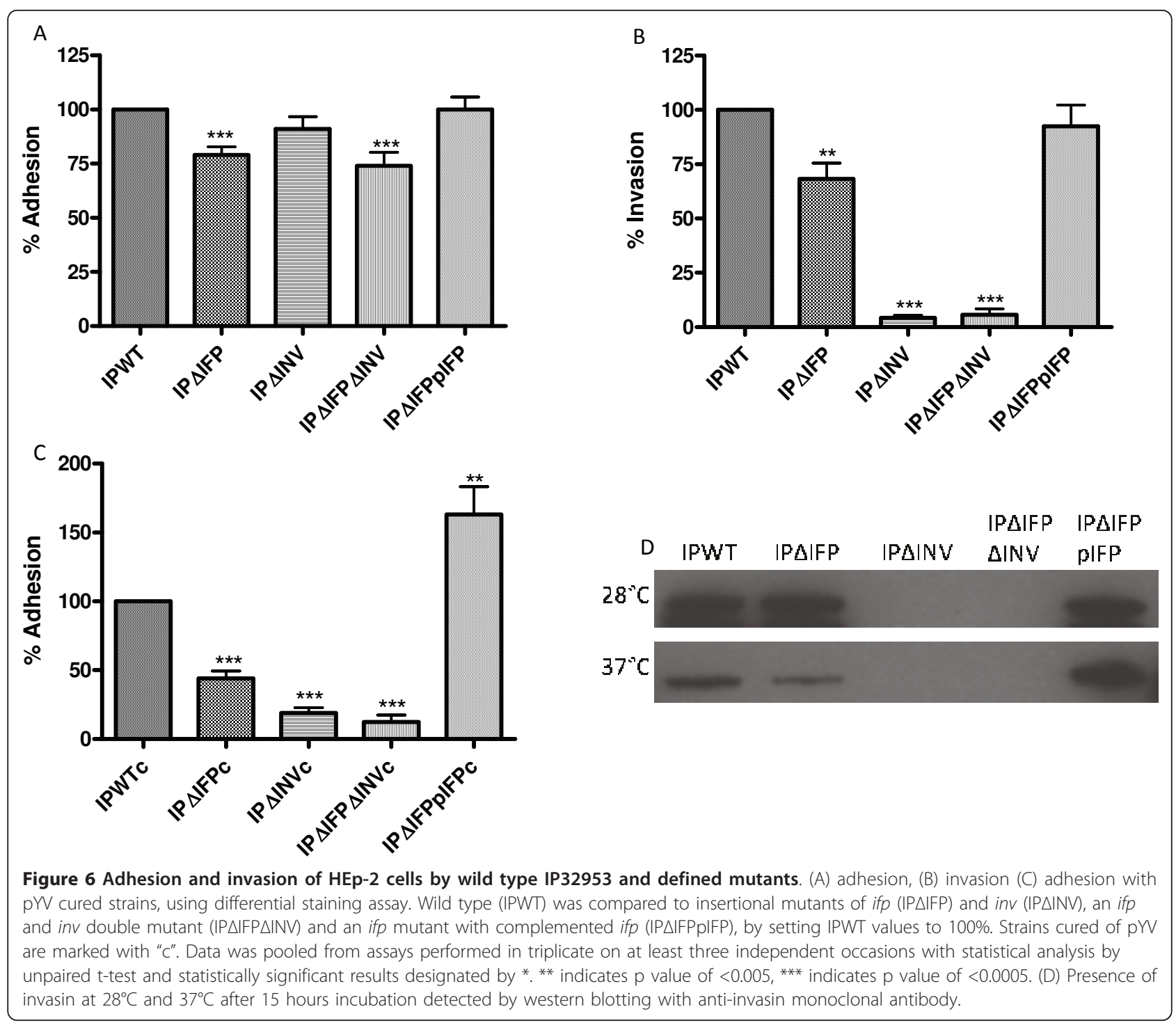

in both Ifp and invasin (Figure 1). Only W776 was not conserved in Ifp and invasin. These cysteine and tryptophan residues are involved in receptor binding by intimin $[27,30]$ and therefore may have a role in Ifp receptor binding.

We demonstrated direct binding of Ifp using both flow cytometry and fluorescence microscopy, where the MBP-Ifp fusion proteins could bind to HEp-2 cells. By contrast the MBP alone did not bind and the specific cysteine residue mutant MBP-Iff C337G $_{\text {showed greatly }}$ reduced levels of binding (Figures 3 and 4). This reduced level of binding with the MBP-Ifp ${ }_{\mathrm{C} 337 \mathrm{G}}$ shows that the cysteine residue is important to allow Ifp binding. The same cysteine residue is known to be important in both intimin and invasin, through the formation of a disulphide bond $[18,29]$, therefore it may be that the cysteine has a similar role in Ifp. The width of the
FACS fluorescence intensity graph suggests that MBPIfp does not bind uniformly to all cells (Figure 3 ). This was confirmed by confocal microscopy, where the cells which were exposed to the MBP-Ifp fusion protein, showed a pattern of fluorescence of intensely stained localised areas, instead of scattered fluorescence across the cell surface. A similar pattern of adherence was observed when HEp- 2 cells were incubated with MBP fusion proteins of intimin and invasin [18]. As invasin is known to bind to $\beta 1$ integrins and it has been suggested that intimin can bind to $\beta 1$ integrin $[13,24,25]$ co-localisation of Ifp to $\beta 1$ integrin was investigated (Figure $5 \mathrm{~B}$ ). As no co-localisation was observed it shows that Ifp binds to alternative receptors on the cell surface. Lipid rafts are sphingolipid and cholesterol rich regions of the plasma membrane, into which Tir is thought to be transferred $[47,48]$. Additionally uropathogenic E. coli 


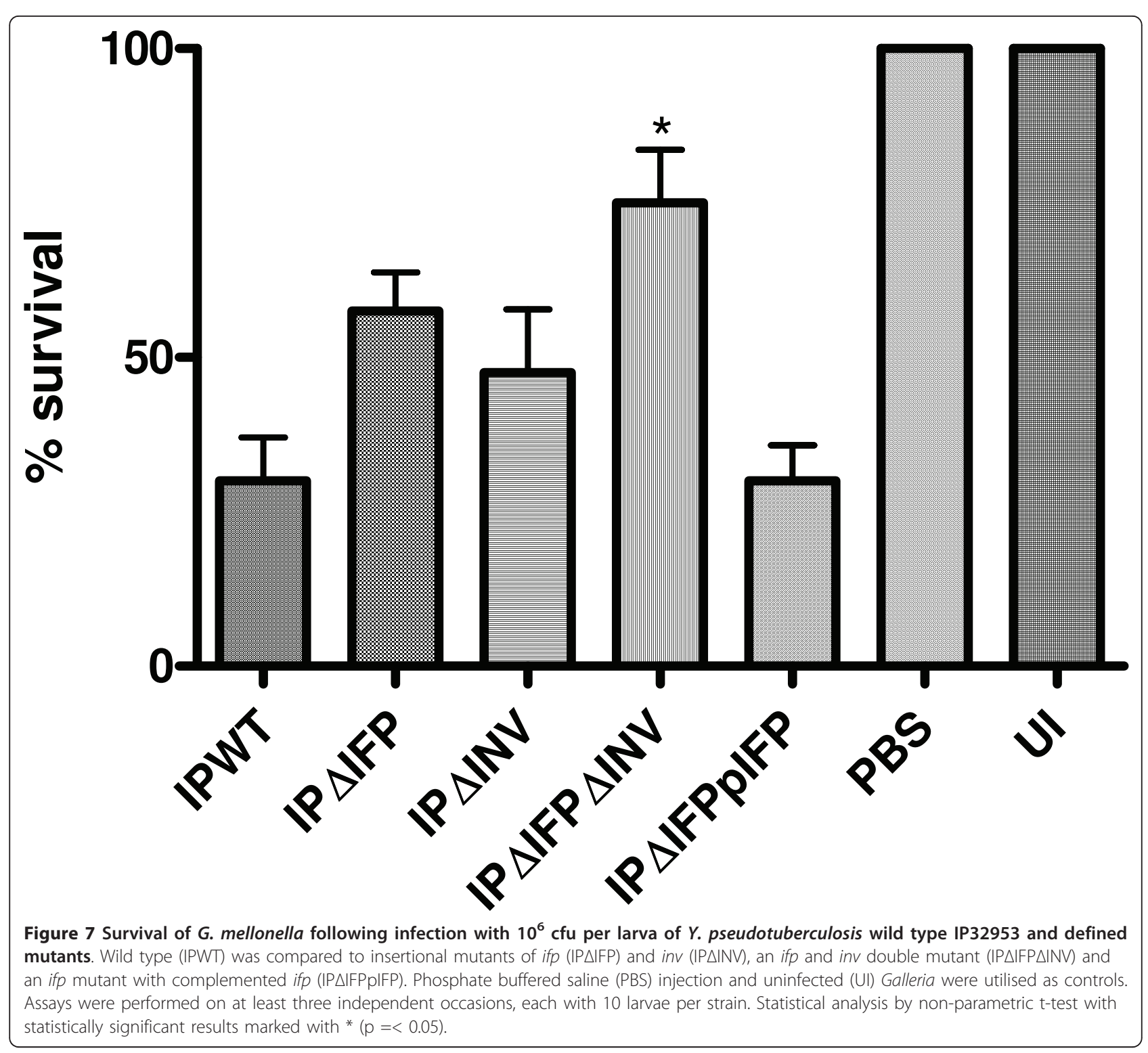

are known to invade via lipid rafts [49], and Salmonella and Shigella sp. use a type three secretion system to translocate effectors, by binding to cholesterol within lipid rafts [50]. To investigate if MBP-Ifp was binding to a component of these lipid rafts, co-localisation of MBP-Ifp to CD59 was undertaken by confocal microscopy. CD59 was selected as it is known to localise to these micro-domains and could therefore act as a marker. The results show co-localisation of Ifp and CD59,

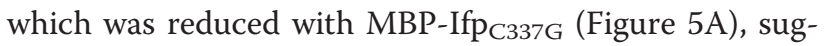
gesting that there is a putative receptor for Ifp within these lipid rafts. The Ifp receptor within these lipid rafts has yet to be determined, but as not all of the MBP-Ifp co-localised, no conclusions can currently be made as to the exact receptor of Ifp.
Inv is differentially thermoregulated with lower levels being expressed at $37^{\circ} \mathrm{C}$ compared to $28^{\circ} \mathrm{C}$ [38]. In comparison, yadA shows maximal expression at $37^{\circ}$ $\mathrm{C}$ in exponential phase culture, conditions where inv expression is repressed [51]. YadA is a virulence plasmid (pYV) encoded adhesin, known to be involved during the infection of $Y$. pseudotuberculosis [51-53]. The pattern of inv expression was confirmed by this study, where inv was expressed both at $28^{\circ} \mathrm{C}$ and $37^{\circ} \mathrm{C}$ during lag and early log phase culture, although at a greater degree at $28^{\circ} \mathrm{C}$ (Figure 2). The ifp gene appears to be expressed at $37^{\circ} \mathrm{C}$ at a later time point in the late log or early stationary phase, when $i n v$ expression is reduced. As ifp and yadA are expressed at similar time points and at the same temperature, Ifp may 
have a similar role to YadA during the infection of $Y$. pseudotuberculosis [51]. Although inv expression is decreased at a later time point, it still appears to have an effect on the invasion of $Y$. pseudotuberculosis (Figure 6B); this is despite using stationary phase cultures which had been grown at $37^{\circ} \mathrm{C}$. The western blot analysis for presence of invasin under these conditions (Figure 6D), confirmed that although inv may no longer be actively expressed, invasin was still present in the cell and could therefore have a role in invasion of HEp-2 cells.

The invasion and adhesion assays confirmed the microscopy and flow cytometry results, in demonstrating a role for Ifp as an adhesin, as the levels of adhesion were reduced with IP $\triangle$ IFP in comparison to wild type (Figure 6A). The inv mutant did not show as great a decrease in adhesion as the ifp mutant, but the double mutant showed similar if not a marginally greater reduction in adhesion as IPAIFP, in comparison to the wild type. Although levels of invasion were significantly affected by IP $\triangle$ IFP, this may be due to reduced adhesion, suggesting that Ifp is an adhesin. Any differences between IP $\triangle I N V$ and IP $\triangle I F P \triangle I N V$ were beyond the detection capability of this assay, but it appeared that invasin was the dominant protein involved in the invasion of the HEp-2 cells. Removal of the pYV and therefore the YadA and Yop virulence factors allowed greater distinction of the role of Ifp. Without these extra virulence determinants compensating for the mutation of ifp, the IP $\triangle$ IFP mutant showed a statistically significant reduction in adhesion compared to IPWT (Figure 6C). This confirms the role of Ifp as an adhesin of $Y$. pseudotuberculosis.

As G. mellonella possesses an innate immune system with structural and functional similarities to the mammalian innate immune system, it is a useful alternative to the traditional murine yersiniosis infection model, to examine virulence in vivo, especially as unlike the C. elegans model, G. mellonella can be incubated at $37^{\circ} \mathrm{C}$ $[42,54]$. Previous studies with $Y$. pseudotuberculosis comparing G. mellonella and the murine model, showed that G. mellonella could reflect infection in mammals and therefore could be useful as a higher throughput screen of mutants, before a more in depth analysis was undertaken in the murine model [42]. In this study the G. mellonella model demonstrated a role for Ifp in the pathogenesis of $Y$. pseudotuberculosis, in particular in concert with invasin, as the double mutant showed a significant increase in survival compared to the wild type (Figure 7). There also appeared to be mild attenuation in virulence with both of the single mutants. This suggests that Ifp, together with invasin, does have a role in virulence of $Y$. pseudotuberculosis in this infection model.

\section{Conclusions}

We have shown the presence of a novel functional adhe$\sin$ in $Y$. pseudotuberculosis that has been mutated with an IS element and is presumably non-functional in $Y$. pestis. Ifp is expressed during late log to early stationary phase at $37^{\circ} \mathrm{C}$ and demonstrates an ability to bind to HEp-2 cells in vitro, which can be disrupted by mutation of the gene, or even a single cysteine residue. Together with invasin and intimin, Ifp is a new member of a family of outer membrane adhesins that is activated at $37^{\circ} \mathrm{C}$ and may act at a later stage than invasin during infection.

\section{Additional material}

Additional file 1: Amino acid alignment of Ifp from the four currently sequenced genomes of $Y$. pseudotuberculosis. Utilising the ClustalW program, the amino acid sequences of $Y$. pseudotuberculosis strains IP32953, IP31758, PB1 and YPIII were aligned.

Additional file 2: Growth curves from the temporal expression of Ifp and invasin assay. Within the Anthos Lucyl combined photometer and luminometer, OD readings at $600 \mathrm{~nm}$ were taken at 30 minute intervals and used to construct these growth curves. Cultures were incubated at (A) $24^{\circ} \mathrm{C}$ (B) $28^{\circ} \mathrm{C}$ and (C) $37^{\circ} \mathrm{C}$.

\section{Acknowledgements}

We are grateful to G. Frankel, Imperial College, London, UK for the intimin advice; E. Carniel, Institut Pasteur, Paris, France for the Y. pseudotuberculosis strain IP32953 and the PKOBEG vector; A. Darwin, NYU School of Medicine, New York, USA for the PAJD434 plasmid; and R. Isberg, Tufts University, Boston, USA for the gift of the anti-invasin monoclonal antibody. We thank DSTL for financial support for this project.

\section{Author details}

${ }^{1}$ Pathogen Molecular Biology Unit, Department of Infectious and Tropical Diseases, London School of Hygiene and Tropical Medicine, London, WC1E 7HT, UK. ${ }^{2}$ School of Molecular and Medical Sciences, Queens Medical Centre, University of Nottingham, Nottingham, NG7 2UH, UK. ${ }^{3}$ School of Biosciences, University of Exeter, Geoffrey Pope Building, Stocker Road, Exeter, EX4 4QD, UK.

\section{Authors' contributions}

All authors read and approved the manuscript and contributed to experimental design. PS and BW contributed to manuscript preparation.

Received: 4 January 2011 Accepted: 28 April 2011

Published: 28 April 2011

\section{References}

1. Achtman M, Zurth K, Morelli G, Torrea G, Guiyoule A, Carniel E: Yersinia pestis, the cause of plague, is a recently emerged clone of Yersinia pseudotuberculosis. Proc Natl Acad Sci USA 1999, 96(24):14043-14048.

2. Wren BW: The yersiniae - a model genus to study the rapid evolution of bacterial pathogens. Nat Rev Microbiol 2003, 1(1):55-64.

3. Chain PS, Carniel E, Larimer FW, Lamerdin J, Stoutland PO, Regala WM Georgescu AM, Vergez LM, Land ML, Motin VL, et al: Insights into the evolution of Yersinia pestis through whole-genome comparison with Yersinia pseudotuberculosis. Proc Natl Acad Sci USA 2004, 101(38):13826-13831.

4. Hinchliffe SJ, Isherwood KE, Stabler RA, Prentice MB, Rakin A, Nichols RA, Oyston PC, Hinds J, Titball RW, Wren BW: Application of DNA microarrays to study the evolutionary genomics of Yersinia pestis and Yersinia pseudotuberculosis. Genome Res 2003, 13(9):2018-2029. 
5. Sokurenko EV, Hasty DL, Dykhuizen DE: Pathoadaptive mutations: gene loss and variation in bacterial pathogens. Trends Microbiol 1999, 7(5):191-195.

6. Torres AG, Vazquez-Juarez RC, Tutt CB, Garcia-Gallegos JG: Pathoadaptive mutation that mediates adherence of shiga toxin-producing Escherichia coli 0111. Infect Immun 2005, 73(8):4766-4776

7. Day WA Jr, Fernandez RE, Maurelli AT: Pathoadaptive mutations that enhance virulence: genetic organization of the cadA regions of Shigella spp. Infect Immun 2001, 69(12):7471-7480.

8. Sun YC, Hinnebusch BJ, Darby C: Experimental evidence for negative selection in the evolution of a Yersinia pestis pseudogene. Proc Natl Acad Sci USA 2008, 105(23):8097-8101.

9. Erickson DL, Jarrett CO, Callison JA, Fischer ER, Hinnebusch BJ: Loss of a biofilm-inhibiting glycosyl hydrolase during the emergence of Yersinia pestis. J Bacterio/ 2008, 190(24):8163-8170.

10. Rosqvist R, Skurnik M, Wolf-Watz H: Increased virulence of Yersinia pseudotuberculosis by two independent mutations. Nature 1988, 334(6182):522-524.

11. Bliska JB, Copass MC, Falkow S: The Yersinia pseudotuberculosis adhesin YadA mediates intimate bacterial attachment to and entry into HEp-2 cells. Infect Immun 1993, 61(9):3914-3921.

12. Isberg RR, Falkow S: A single genetic locus encoded by Yersinia pseudotuberculosis permits invasion of cultured animal cells by Escherichia coli K-12. Nature 1985, 317(6034):262-264.

13. Isberg RR, Leong JM: Multiple $\beta 1$ chain integrins are receptors for invasin, a protein that promotes bacterial penetration into mammalian cells. Cell 1990, 60(5):861-871.

14. Clark MA, Hirst BH, Jepson MA: M-cell surface $\beta 1$ integrin expression and invasin-mediated targeting of Yersinia pseudotuberculosis to mouse Peyer's patch M cells. Infect Immun 1998, 66(3):1237-1243.

15. Hamburger ZA, Brown MS, Isberg RR, Bjorkman PJ: Crystal structure of invasin: a bacterial integrin-binding protein. Science 1999 286(5438):291-295

16. Leong JM, Fournier RS, Isberg RR: Identification of the integrin binding domain of the Yersinia pseudotuberculosis invasin protein. Embo J 1990, 9(6):1979-1989.

17. Chen HD, Frankel G: Enteropathogenic Escherichia coli: unravelling pathogenesis. FEMS Microbiol Rev 2005, 29(1):83-98.

18. Frankel G, Candy DC, Everest P, Dougan G: Characterization of the C terminal domains of intimin-like proteins of enteropathogenic and enterohemorrhagic Escherichia coli, Citrobacter freundii, and Hafnia alvei. Infect Immun 1994, 62(5):1835-1842.

19. Kelly G, Prasannan S, Daniell S, Fleming K, Frankel G, Dougan G, Connerton I, Matthews S: Structure of the cell-adhesion fragment of intimin from enteropathogenic Escherichia coli. Nat Struct Biol 1999, 6(4):313-318

20. Jerse AE, Kaper JB: The eae gene of enteropathogenic Escherichia coli encodes a 94-kilodalton membrane protein, the expression of which is influenced by the EAF plasmid. Infect Immun 1991, 59(12):4302-4309.

21. Deibel C, Kramer S, Chakraborty T, Ebel F: EspE, a novel secreted protein of attaching and effacing bacteria, is directly translocated into infected host cells, where it appears as a tyrosine-phosphorylated $90 \mathrm{kDa}$ protein. Mol Microbiol 1998, 28(3):463-474

22. Kenny B, DeVinney R, Stein M, Reinscheid DJ, Frey EA, Finlay BB: Enteropathogenic E. coli (EPEC) transfers its receptor for intimate adherence into mammalian cells. Cell 1997, 91(4):511-520.

23. Knutton S, Baldwin T, Williams PH, McNeish AS: Actin accumulation at sites of bacterial adhesion to tissue culture cells: basis of a new diagnostic test for enteropathogenic and enterohemorrhagic Escherichia coli. Infect Immun 1989, 57(4):1290-1298.

24. Sinclair JF, Dean-Nystrom EA, O'Brien AD: The established intimin receptor Tir and the putative eucaryotic intimin receptors nucleolin and $\beta 1$ integrin localize at or near the site of enterohemorrhagic Escherichia coli 0157:H7 adherence to enterocytes in vivo. Infect Immun 2006, 74(2):1255-1265.

25. Frankel G, Lider O, Hershkoviz R, Mould AP, Kachalsky SG, Candy DC, Cahalon L, Humphries MJ, Dougan G: The cell-binding domain of intimin from enteropathogenic Escherichia coli binds to $\beta 1$ integrins. J Biol Chem 1996, 271(34):20359-20364

26. Sinclair JF, O'Brien AD: Intimin types $a, \beta$, and $\gamma$ bind to nucleolin with equivalent affinity but lower avidity than to the translocated intimin receptor. J Biol Chem 2004, 279(32):33751-33758.
27. Reece S, Simmons CP, Fitzhenry RJ, Batchelor M, Hale C, Matthews S, Phillips AD, Dougan G, Frankel G: Mutagenesis of conserved tryptophan residues within the receptor-binding domain of intimin: influence on binding activity and virulence. Microbiology 2002, 148(Pt 3):657-665

28. Frankel G, Candy DC, Fabiani E, Adu-Bobie J, Gil S, Novakova M, Phillips AD, Dougan G: Molecular characterization of a carboxy-terminal eukaryoticcell-binding domain of intimin from enteropathogenic Escherichia coli. Infect Immun 1995, 63(11):4323-4328.

29. Leong JM, Morrissey PE, Isberg RR: A 76-amino acid disulfide loop in the Yersinia pseudotuberculosis invasin protein is required for integrin receptor recognition. J Biol Chem 1993, 268(27):20524-20532.

30. Batchelor M, Prasannan S, Daniell S, Reece S, Connerton I, Bloomberg G, Dougan G, Frankel G, Matthews S: Structural basis for recognition of the translocated intimin receptor (Tir) by intimin from enteropathogenic Escherichia coli. Embo J 2000, 19(11):2452-2464.

31. Riley G, Toma S: Detection of pathogenic Yersinia enterocolitica by using congo red-magnesium oxalate agar medium. J Clin Microbiol 1989, 27(1):213-214

32. Atkinson $\mathrm{S}$, Chang $\mathrm{CY}$, Patrick $\mathrm{HL}$, Buckley $\mathrm{CM}$, Wang $\mathrm{Y}$, Sockett RE, Camara M, Williams P: Functional interplay between the Yersinia pseudotuberculosis YpsRI and YtbRI quorum sensing systems modulates swimming motility by controlling expression of flhDC and fliA. Mol Microbiol 2008.

33. Maxson ME, Darwin AJ: Identification of inducers of the Yersinia enterocolitica phage shock protein system and comparison to the regulation of the RpoE and Cpx extracytoplasmic stress responses. J Bacteriol 2004, 186(13):4199-4208.

34. Guzman LM, Belin D, Carson MJ, Beckwith J: Tight regulation, modulation, and high-level expression by vectors containing the arabinose $\mathrm{PBAD}$ promoter. J Bacteriol 1995, 177(14):4121-4130.

35. Dersch P, Isberg RR: A region of the Yersinia pseudotuberculosis invasin protein enhances integrin-mediated uptake into mammalian cells and promotes self-association. Embo J 1999, 18(5):1199-1213.

36. Parkhill J, Wren BW, Thomson NR, Titball RW, Holden MT, Prentice MB, Sebaihia M, James KD, Churcher $C$, Mungall KL, et al: Genome sequence of Yersinia pestis, the causative agent of plague. Nature 2001, 413(6855):523-527.

37. Needleman SB, Wunsch CD: A general method applicable to the search for similarities in the amino acid sequence of two proteins. $J \mathrm{Mol} B \mathrm{BO}$ 1970, 48(3):443-453.

38. Isberg RR, Swain A, Falkow S: Analysis of expression and thermoregulation of the Yersinia pseudotuberculosis inv gene with hybrid proteins. Infect Immun 1988, 56(8):2133-2138.

39. Munro S: Lipid rafts: elusive or illusive? Cell 2003, 115(4):377-388.

40. Clark L, Martinez-Argudo I, Humphrey TJ, Jepson MA: GFP plasmid-induced defects in Salmonella invasion depend on plasmid architecture, not protein expression. Microbiology 2009, 155(Pt 2):461-467.

41. Seed KD, Dennis JJ: Development of Galleria mellonella as an alternative infection model for the Burkholderia cepacia complex. Infect Immun 2008, 76(3):1267-1275

42. Champion OL, Cooper IA, James SL, Ford D, Karlyshev A, Wren BW, Duffield M, Oyston PC, Titball RW: Galleria mellonella as an alternative infection model for Yersinia pseudotuberculosis. Microbiology 2009 155(Pt 5):1516-1522.

43. Lerat $\mathrm{E}$, Ochman $\mathrm{H}$ : Recognizing the pseudogenes in bacterial genomes. Nucleic Acids Res 2005, 33(10):3125-3132

44. Song Y, Tong Z, Wang J, Wang L, Guo Z, Han Y, Zhang J, Pei D, Zhou D, Qin $H$, et al: Complete genome sequence of Yersinia pestis strain 91001 an isolate avirulent to humans. DNA Res 2004, 11(3):179-197.

45. Simonet M, Riot B, Fortineau N, Berche P: Invasin production by Yersinia pestis is abolished by insertion of an IS200-like element within the inv gene. Infect Immun 1996, 64(1):375-379.

46. Pallen MJ, Wren BW: Bacterial pathogenomics. Nature 2007, 449(7164):835-842

47. Simons K, Ikonen E: Functional rafts in cell membranes. Nature 1997 387(6633):569-572

48. Hayward RD, Hume PJ, Humphreys D, Phillips N, Smith K, Koronakis V: Clustering transfers the translocated Escherichia coli receptor into lipid rafts to stimulate reversible activation of c-Fyn. Cell Microbiol 2009, 11(3):433-441 
49. Baorto DM, Gao Z, Malaviya R, Dustin ML, van der Merwe A, Lublin DM, Abraham SN: Survival of FimH-expressing enterobacteria in macrophages relies on glycolipid traffic. Nature 1997, 389(6651):636-639.

50. Hayward RD, Cain RJ, McGhie EJ, Phillips N, Garner MJ, Koronakis V: Cholesterol binding by the bacterial type III translocon is essential for virulence effector delivery into mammalian cells. Mol Microbiol 2005, 56(3):590-603

51. Eitel J, Dersch P: The YadA protein of Yersinia pseudotuberculosis mediates high-efficiency uptake into human cells under environmental conditions in which invasin is repressed. Infect Immun 2002, 70(9):4880-4891.

52. Hudson $\mathrm{K}$, Bouton AH: Yersinia pseudotuberculosis adhesins regulate tissue-specific colonization and immune cell localization in a mouse model of systemic infection. Infect Immun 2006, 74(11):6487-6490.

53. El Tahir Y, Skurnik M: YadA, the multifaceted Yersinia adhesin. Int J Med Microbiol 2001, 291(3):209-218

54. Mowlds P, Kavanagh K: Effect of pre-incubation temperature on susceptibility of Galleria mellonella larvae to infection by Candida albicans. Mycopathologia 2008, 165(1):5-12.

doi:10.1186/1471-2180-11-85

Cite this article as: Strong et al: Identification and characterisation of a novel adhesin Ifp in Yersinia pseudotuberculosis. BMC Microbiology 2011 11:85.

\section{Submit your next manuscript to BioMed Central} and take full advantage of:

- Convenient online submission

- Thorough peer review

- No space constraints or color figure charges

- Immediate publication on acceptance

- Inclusion in PubMed, CAS, Scopus and Google Scholar

- Research which is freely available for redistribution

Submit your manuscript at www.biomedcentral.com/submit 